\title{
As contribuições de Robert Cooper para o debate sobre ontologia organizacional
}

\author{
EVERTON RODRIGUES DA SILVA \\ Universidade Federal de Minas Gerais / Faculdade de Administração, Contabilidade e EConomia, \\ Programa de Pós-Graduação em Administração, Belo Horizonte - MG, Brasil
}

Dimitri Augusto da CUnha TOledo

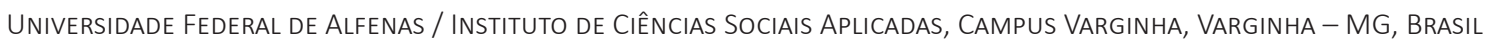

\section{Resumo}

Este artigo, elaborado a partir das contribuições de Robert Cooper, busca pensar uma ontologia organizacional que se distancie das concepções teóricas da administração ligadas à ciência moderna, aproximando-se de uma perspectiva pós-moderna. Após breve contextualização do tema, apresentamos os princípios conceituais que fundamentam o pensamento moderno e suas implicações para a teorização organizacional, bem como suas limitações. Em seguida, descrevemos as bases do ponto de vista pós-moderno e seus desdobramentos. Finalizamos sugerindo que as organizações sejam reconhecidas como acontecimentos inventivos múltiplos, que surpreendem o previsto e acentuam o caráter emergente da realidade social. As ideias de Cooper suscitam uma epistemologia focada na descrição e interpretação da organização como processo, isto é, na captura do presente etnográfico organizacional. As organizações, sendo objetos empíricos, prosseguem vivas, ativas, híbridas, fragmentadas. Como diria Bruno Latour, jamais fomos modernos e nossas organizações também não foram ou não são modernas.

Palavras-chave: Ontologia organizacional. Organização/desorganização. Pós-modernismo. Robert Cooper. Jacques Derrida.

\section{Robert Cooper's contributions to the debate on organizational ontology}

\begin{abstract}
This article, prepared through Robert Cooper's contributions, seek to think of an organizational ontology that moves away from the theoretical conceptions of administration linked to modern science, getting closer to a postmodern perspective. After a brief contextualization of the theme, we introduce the conceptual principles that ground modern thinking and their implications to organizational theorization, as well as their limitations. Next, we describe foundations from the postmodern viewpoint and their unfolding. Finally, we suggest that organizations are recognized as multiple inventive events, which surprise in relation to what was predicted and accentuate the emergent character of social reality. Cooper's ideas give rise to an epistemology focused on describing and interpreting the organization as a process, i.e. capturing the organizational ethnographic moment. Organizations, as empirical objects, keep living, active, hybrid, fragmented. As Bruno Latour might say, we have never been modern and our organizations were not or are not modern as well.
\end{abstract}

Keywords: Organizational ontology. Organization/disorganization. Postmodernism. Robert Cooper. Jacques Derrida.

\section{Las contribuciones de Robert Cooper al debate sobre la ontología organizacional}

\section{Resumen}

Este trabajo, elaborado desde las contribuciones de Robert Cooper, busca pensar una ontología organizacional que se aleje de las concepciones teóricas de la administración asociadas con la ciencia moderna, acercándose a una perspectiva posmoderna. Después de una contextualización del tema, empezamos a presentar los principios conceptuales que subyacen el pensamiento moderno y sus implicaciones para la teorización organizacional, así como sus limitaciones. Entonces describimos las bases de la perspectiva posmoderna y sus consecuencias. Finalizamos sugiriendo que las organizaciones sean reconocidas como acontecimientos inventivos múltiples, que sorprenden los planes y acentúan el carácter emergente de la realidad social. Las ideas de Cooper suscitan a una epistemología enfocada en la descripción y comprensión de la organización como un proceso, es decir, en la captura del presente etnográfico organizacional. Las organizaciones, como objetos empíricos, continúan vivas, activas, híbridas, fragmentadas. Como dice Bruno Latour, jamás hemos sido modernos, y nuestras organizaciones tampoco han sido o son modernas.

Palabras clave: Ontología Organizacional. Organización/desorganización. Posmodernismo. Robert Cooper. Jacques Derrida.

Artigo submetido em 10 de agosto de 2014 e aceito para publicação em 2 de outubro de 2015.

DOI: http://dx.doi.org/10.1590/1679-395131382 


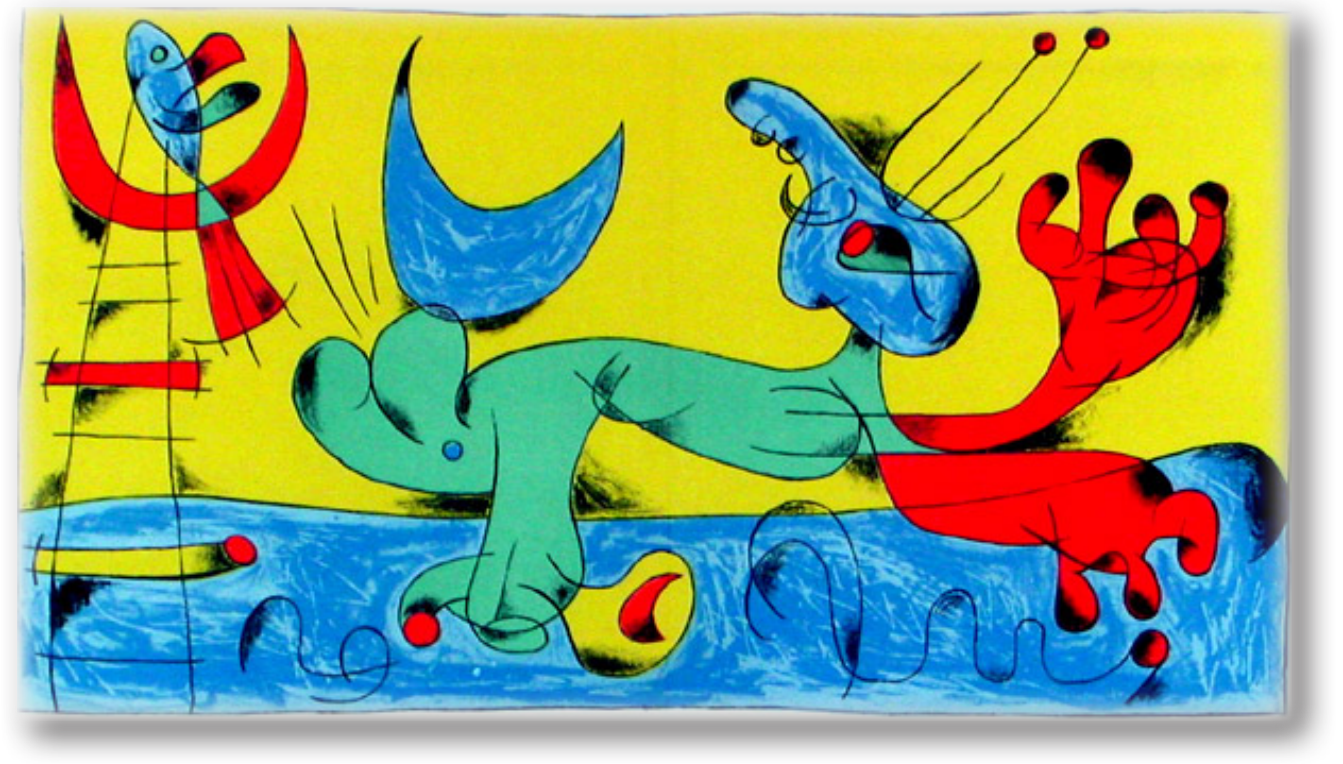

\section{INTRODUÇÃO}

As grandes unidades industriais nascentes no final do século XIX simbolizaram um novo modo de organização da sociedade, que Reed (2010) denominou de "estado administrativo". Nesse período histórico, a organização nasce como uma forma hierárquica necessária para mediar as relações entre os interesses coletivos e individuais, sendo considerada o instrumento que garantiria a passagem de uma sociedade dita desorganizada, (portanto, vista como arcaica e primitiva) para um mundo organizado e civilizado (dito moderno), constituindo-se num meio de assegurar ordenamento e progresso sociais. As organizações anunciavam o triunfo do conhecimento racional e da técnica sobre a emoção e o preconceito humano, aparentemente intratáveis, aponta Reed (2010). Tal concepção influenciou a natureza dos estudos administrativos, de tal forma que se imagina que esse modo de interpretar a organização, que emergiu na transição dos séculos XIX para o XX, representa a lógica universal de funcionamento da organização (REED, 2010; ZILIO, BARCELLOS, DELLAGNELO et al., 2012) que deve ser difundida como a forma correta de gerir. Rafael Alcadipani, no início de seu ensaio Academia e a fábrica de sardinhas, exemplifica o argumento básico que fundamenta a oposição de uma parcela significativa de autores do campo dos estudos organizacionais (EORs) a esse pensamento.

A luta em uma guerra, a elaboração de plantações ou até mesmo o adestramento de animais requer que alguma forma de gerenciamento seja praticada. Por isso, não podemos pensar a sociedade, mesmo que a mais rudimentar, sem a função gestão. Não obstante, ensinamos aos nossos alunos dos cursos de graduação que o "pai" da administração é um engenheiro norte-americano que realizava, entre outras coisas, estudos de tempos e movimentos. Frederick Taylor não inventou a administração. Seu principal legado foi popularizar a racionalização extrema e metódica como sinônimo da melhor maneira de se administrar e gerar resultados em organizações. O taylorismo foi utilizado pelo mundo como a solução para os problemas das empresas ao, pretensamente, indicar a forma correta e certa de gerir. Apresentou-se como aplicável para todo e qualquer tipo de organização, não importando seu contexto e especificidades. Era, ainda, considerado neutro, ou seja, como um conjunto de ferramentas que favorece o melhor resultado, nada além disso. (ALCADIPANI, 2011, p. 345)

\footnotetext{
* Fonte: Joan Miró. Disponível em:<http://spaightwoodgalleries.com/Pages/Miro_1956_Prevert.html>. Acesso em 22 fev. 2016.
} 
Nas últimas décadas, autores do campo dos $\mathrm{EORs}^{1}$ vêm construindo uma posição contrária à ontologia organizacional fundamentada no paradigma moderno de ciência, expresso no conceito de organização burocrática e de seus variantes afins. ${ }^{2}$ Argumentam tais pensadores que as teorias "tradicionais" ${ }^{3}$ da administração constroem conhecimentos propagados como ideologicamente neutros (essa suposta neutralidade provém de sua base científica) e universais que excluem saberes concorrentes e afasta os saberes práticos adquiridos na vivência cotidiana, como mencionam Carrieri, Perdigão e Aguiar (2014). Afirmam também que aqueles que se filiam a essa perspectiva terminam por produzir uma concepção reificada sobre a organização, ao minimizar (ou retirar) o papel do contexto socio-histórico na construção do conhecimento e reproduzir um padrão hegemônico de poder presente nas tecnologias de gestão, majoritariamente euro-americanas. Nesse percurso, operam-se inclusões e exclusões de saberes, surgem disputas pela verdade e configuram-se redes de poder.

[...] a desvalorização desses saberes "empíricos" está associada não, necessariamente, a uma atitude deliberada de gestores, acadêmicos e consultores. Ela se relaciona a um movimento próprio ao capitalismo, que não confere valor a esses saberes que são transmitidos por meio das relações estabelecidas a partir de lógicas que lhe são estranhas e que circulam em virtude de laços familiares ou afetivos, sendo adquiridos, construídos e significados na cotidianidade. Relaciona-se ainda às disputas pelo poder de dizer a verdade, elemento importante da constituição de nossa sociedade. (BARROS, COSTA, XAVIER et al., 2011, p. 46)

Esse grupo de autores defende que cabem aos pesquisadores desvelar o cotidiano organizacional, no sentido de fomentar um olhar plural sobre as práticas administrativas, inibindo o discurso monolítico, dado que a realidade da gestão é múltipla e deve ser observada nas táticas diárias de sobrevivência, no "aqui e agora".

Endossamos a visão crítica dos pensadores citados e entendemos que enxergar as organizações a partir de suas categorias tradicionais de análise - hierarquia, porte, eficiência/eficácia econômica e relação entre as áreas funcionais, entre outras -, centradas num paradigma científico moderno, que privilegia o entendimento da realidade como um estado de ordem e estabilidade, ${ }^{4}$ significa manter-se preso a uma janela mental (citando COOPER, 1990) que reproduz o conhecimento naturalizado da gestão. Tais discursos de garantia de ordem moldaram a história das ideias na administração, de tal forma que se supõe que essa seria a única lógica possível para se pensar o trabalho de gestão (COOPER, 1989; 1990; COOPER e BURREL, 1988; REED, 1994; 2010; TSOUKAS e CHIA, 2002; ZILIO, BARCELLOS, DELLAGNELO et al., 2012).

Foucault (1992) sugere que a epistéme de uma época é um dispositivo discursivo, que permite a seleção de enunciados possíveis no interior de um campo científico, isto é, que possibilita o julgamento do que é qualificável ou não na ciência, tornando-se um meio de ordenação do saber-poder. Dessa perspectiva, acreditamos que a concepção sobre a ontologia organizacional termina por produzir significados limitados sobre a prática acadêmica em Administração, fato que confere relevância ao propósito deste artigo.

\footnotetext{
${ }^{1}$ Referimo-nos aos trabalhos de Alcadipani (2011), Alcadipani e Caldas (2012), Alcadipani e Davel (2003), Alcadipani, Khan, Gantman et al. (2012), Cooper (1989; 1990), Cooper e Burrel (1988), Frenkel e Shenhav (2006), Ibarra-Colado (2006) e Mattos (2009).

${ }^{2}$ Referimo-nos, por exemplo, ao conceito de organização gerencialista (ou pós-burocrática). Embora esse modelo organizacional, na ótica de seus criadores (Peter Drucker, Tom Peters etc.), tenha se fundamentado na crítica às organizações burocráticas, Paes de Paula (2005) desconstrói esse discurso, mostrando que o movimento gerencialista (o management) é uma adaptação do modelo burocrático ao novo contexto histórico. Por esse olhar, ambos compartilham vários aspectos, como nos mostra Paes de Paula: a crença na racionalidade instrumental, na performance, no sucesso, no controle e na alienação da força de trabalho como elementos centrais da cultura administrativa; nas rotinas, procedimentos e nas tecnologias gerenciais como dispositivos ordenadores das atividades coletivas; numa visão idealista/esquemática do mundo, que termina por ignorar a complexidade da gestão; no comprometimento ideológico com o livre mercado; e, em certa negligência, dos aspectos sociopolíticos inerentes às práticas administrativas. ${ }^{3}$ As expressões "teoria tradicional" ou "teoria convencional" serão utilizadas como uma referência ao conjunto de teorias administrativas inspiradas na tradição científica moderna, que ocupam uma posição hegemônica nas ciências administrativas (pensamos aqui no management e menos no subcampo de EORs).

${ }^{4}$ Ferreira, Calvoso e Gonzales (2002) afirmam que a ciência moderna apoia-se numa visão da realidade fundamentada em regularidades e regida por leis independentes do sujeito que a conhece, configurando uma concepção ontoepistemológica objetivista. Adiante, desenvolveremos a concepção do modernismo e suas implicações na administração.
} 
O discurso sobre o significado da organização desencadeia uma série de práticas nos campos da pesquisa relacionadas às escolhas das agendas de pesquisa, à estruturação das linhas de pesquisa, às teorias escolhidas, à reflexão sobre o papel ético das empresas na constituição do mundo contemporâneo etc. Morgan (1980) afirma que, quando os pressupostos utilizados para se fazer ciência não são questionados, corre-se o risco de assumir a visão ortodoxa do campo como o único caminho real e possível (taken-for-granted). Estamos particularmente interessados em refletir sobre esse reducionismo, na medida em que acreditamos que a imagem e a percepção criadas por nós, estudiosos das organizações, fundamentam a ideia sobre nosso objeto de estudo (cf. ALVESSON, 1994; MORGAN, 1980; 1983).

Nesse contexto, o objetivo deste artigo é pensar, a partir das contribuições de Robert Cooper, outra possibilidade de ontologia organizacional (diferente da tradição científica moderna) capaz de consolidar e/ou estimular novas pesquisas no campo de EORs.

\section{AS CONTRIBUIÇÕES DE ROBERT COOPER PARA A ONTOLOGIA ORGANIZACIONAL}

Reed (1994) coloca que debates recentes nos EORs - o autor escreve na década de 1990, mas sua colocação continua tendo validade - focam na dinâmica desorganizadora inerente à mudança estrutural de longo prazo. As teorias organizacionais têm crescentemente questionado a visão de que as sociedades devem ser necessariamente estruturadas em torno de princípios baseados em mecanismos integrativos e reguladores, proporcionados pela burocracia racional. Em seu lugar, emerge uma nova ortodoxia que acredita no necessário debate sobre formas e conteúdos organizacionais flexíveis e nas implicações geradas nas estruturas e práticas, ponto de vista compactuado por Clegg e Hardy (2010).

Esses novos entendimentos sobre como teorizar a prática organizativa sinalizam um desconforto com o domínio de princípios intelectuais vinculados ao paradigma da ciência moderna nas atividades de ensino e pesquisa no campo. Assim, buscamos nesta seção elucidar esses desconfortos e apresentar outra perspectiva para se estudar as organizações.

\section{O modernismo e as organizações}

O modernismo, em sua acepção filosófica, é um momento na história, no qual o homem inventou a si próprio e rejeitou a ideia de que era um reflexo de Deus ou da natureza, colocando a razão como o atributo humano mais significativo (COOPER e BURREL, 1988; MOSÉ, 2012). Os valores fundados na verdade absoluta serão, com a "morte de Deus", substituídos pela crença no sujeito, na consciência (MOSÉ, 2014).

Mosé (2012) lembra que existem dois usos comuns da palavra razão. Aquele que diz respeito à capacidade humana de criar e articular palavras e pensamentos, habilidade que nos diferencia dos animais, pois somente os homens podem criar códigos, palavras e conceitos que operam mediando sua relação com o mundo. Por isso, o homem é visto como o único animal racional ou, mais precisamente, como um animal simbólico e moral, capaz de criar linguagens e valores. $O$ segundo uso refere-se ao emprego de procedimentos específicos para conhecer; isto é, um modelo de pensamento, que erroneamente chamamos de natural (próprio do que é ser um humano), que se tornou orientador da conduta humana e um princípio de explicação da realidade. Nessa última acepção, a razão não se refere à potência de falar, de pensar, de criar códigos, mas a uma forma singular de agir e conhecer "[...] organizada, esclarecida, sem contradições, distante das emoções e, tendo como alvo o incondicional, o imutável, o Ser, a verdade" (MOSÉ, 2012, p. 112). Essa compreensão de razão foi criada pelos gregos clássicos e, posteriormente, transformada por Kant - porém ainda permanecendo vinculada aos princípios metafísicos -, considerado um dos pensadores que inauguram o modernismo filosófico (MOSÉ, 2012; PETERS, 2000). 
Cooper e Burrel (1988) compreendem que o modernismo tem duas variantes principais, que interessam mais diretamente às ciências sociais. ${ }^{5} \mathrm{O}$ (i) modernismo crítico, inspirado em Kant e que tem em Jürgen Habermas um de seus importantes expoentes. A noção kantiana de razão crítica é, praticamente, abandonada pelas teorias organizacionais em favor da criação de uma razão funcional instrumental, que deu origem ao (ii) modernismo sistêmico, inspirado em Auguste Comte e Saint-Simon.

O modernismo sistêmico, fundamentado na invenção do conceito de conhecimento teórico/científico e do modelo de racionalidade instrumental, dominou a teorização e a prática organizacionais. Sua intenção era, por meio do saber racional, estabelecer formas de controle social e de dirigir o ordenamento (as transformações) da sociedade. A questão central era desenvolver sistemas de gestão capazes de controlar a organização complexa que é a sociedade e a própria vida.

A complexidade precisa ser dirigida, para que ela alcance objetivos específicos. Para tanto, devem ser empregadas tecnologias de toda ordem: teoria da informação, a cibernética, teoria da decisão, teoria dos jogos, teoria da utilidade, técnicas de transporte etc. $O$ foco desses dispositivos é a construção de uma ação racional (ou a identificação de novos meios para alcançá-la) orientada para o cumprimento de metas. A incerteza, nesse contexto, é vista como o conjunto de possibilidades que o homem pode conhecer, mas não tem como dominar, na medida em que não se pode quantificar a probabilidade de que certos fatos aconteçam.

A ação racional é, portanto, um tipo específico de ação capaz de produzir/gerar/assegurar o resultado pretendido e minimizar as incertezas (COOPER e BURREL, 1988). Por conseguinte, a lógica do modernismo sistêmico aplicada à teoria organizacional tenta estabelecer princípios de ação que ordene as decisões e as formas de aprendizagem de modo que se gere um tipo de verdade invariante. Essa era a condição, para que as instituições (as cidades e as organizações) pudessem aumentar sua escala de atuação, somente possível com as tecnologias criadas a partir do avanço do conhecimento científico. Os sistemas se complexificam e com isso cresce a exigência de novos mecanismos de coordenação e regulação.

Além da necessidade de controle dos sistemas complexos de grande escala, a busca pela performance (ou produtividade) caracteriza a narrativa organizacional moderna. As organizações devem se basear num principio, simples em sua formulação, de obtenção de mais com menos esforço ou menor custo (em outros termos, na otimização da relação entre input e output organizacionais). Esse critério se desenvolve, ganha relevância intelectual e assume um status de princípio geral das ações corporativas, um princípio de realização e objetificação nomeado, por Cooper e Burrel, de princípio de performatividade. A influência da normatividade das leis no ambiente organizacional é suplantada pela exigência de performatividade, tamanha sua influência na materialidade das organizações, complementam os autores.

Guiada pela necessidade de dirigir arranjos intricados em pleno crescimento e pela exigência de performatividade, a legitimidade das organizações constrói-se em torno de sua capacidade de dominar o seu contexto, como um meio de reduzir as ameaças externas e internas. Nesse enquadramento histórico, as aspirações individuais assumem um papel subordinado ao interesse da organização. Busca-se compatibilizar as ações individuais com os objetivos gerais do sistema, mas de um modo que o funcionamento do sistema não seja perturbado. Lyotard (1984) afirma que os procedimentos administrativos devem fazer com que os indivíduos "desejem" aquilo que o sistema necessita para funcionar bem (COOPER e BURREL, 1988).

Para Cooper e Burrel, embora existam diferenças radicais entre as duas versões do modernismo, ambas compartilham a crença num mundo governado pela razão, ${ }^{6}$ manifestada por meio de dois princípios: (i) o discurso espelha a ordem e a razão que "já estavam lá" no mundo; (ii) há um agente do pensamento, o sujeito, capaz de se tornar consciente (conhe-

\footnotetext{
${ }^{5}$ Peters (2000) adota os termos modernismo/pós-modernismo de um modo distinto de Cooper e Burrel (1988). Em linhas gerais, ele entende que esses movimentos estão vinculados às artes, à arquitetura e aos estudos culturais. Quando deseja se referir a um movimento de cunho filosófico, ele faz uso do par estruturalismo/pós-estruturalismo. Cooper e Burrel adotam uma conceituação mais geral, fazendo referência somente a modernismo/ pós-modernismo. Para os autores, esse binômio diz respeito a um movimento filosófico, a uma epistéme, a um ethos que trazem consigo uma forma de pensar, um sistema de valores e práticas relacionadas à vida em geral e às organizações. Não é o objetivo aqui realizar uma genealogia desses termos. Dada a complexidade de tal feito, adotamos as denominações de Cooper e Burrel, que nos parecem satisfatórias para o propósito deste artigo.

${ }^{6}$ Como dito, seguindo Mosé, o termo razão é empregado como um modelo de pensamento que se sustenta, entre outros aspectos, na crença da ideia de organização como uma extensão da racionalidade humana transcendental, isto é, num tipo específicio de racionalidade que se apoia na busca de um sentido que independa da linguagem, que só pode ser obtido pelo pensamento. O pensamento é compreendido como uma instância de arbitragem superior à vida (essa última vista como mundana e, portanto, imperfeita).
} 
cedor) do mundo exterior. No caso do modernismo sistêmico, o sujeito é o próprio sistema que opera guiado pelas tecnologias de controle e comunicação (somente possíveis pela aplicação de técnicas científicas). Busca-se uma harmonia, estabilidade e um determinismo pelo sistema. ${ }^{7}$ A razão é um atributo do sistema e não das partes. No modernismo crítico, o sujeito é o indivíduo, ou uma rede de interação de indivíduos, que através da comunicação ordinária pode encontrar um consenso universal para a experiência humana (também se busca a harmonia, a estabilidade e o determinismo assegurado pelo conjunto). Há, em ambos, a pressuposição da busca de uma unidade. Persegui-la deve ser o objetivo. Na concepção moderna, a unidade (ou a intenção de alcançá-la) é o que legitima a experiência humana.

Portanto, expressando-nos de um modo mais geral, o que marca o pensamento moderno na teoria organizacional é a supervalorização da ideia de organização como um ente autônomo - uma extensão do sujeito consciente de si - que se sustenta por uma racionalidade autônoma (uma racionalidade científica que se diz universal e a-histórica) capaz de interpretar, decidir, julgar, avaliar e dirigir. A razão científica moderna é autoconfiante, antropocêntrica ${ }^{8}$ e acredita ser o único modo possível de se estabelecer regularidades necessárias para se viver, diante de um mundo (uma natureza) que se apresenta incontrolável e capaz de pôr fim aos projetos da espécie humana (MOSÉ, 2012). Na história intelectual da humanidade, o modernismo inaugura (recupera do pensamento grego e o transforma) uma visão de sujeito que acredita possuir em si mesmo um princípio de ação. Diz Mosé, que a subjetividade moderna apoia-se na crença de que o sujeito é o princípio do pensamento e da ação e que pensar é um acontecimento metafísico isolado dos fatores externos. Nessa perspectiva, o homem (o pensamento humano) é o ponto fixo, o centro da ordenação do mundo, complementa a filósofa.

No entanto, a organização não é o efeito da intenção de quem a dirige. Ela não se reduz a uma síntese resultante dos planos organizacionais. Por via de regra, o que chamamos de organização é uma alusão ao seu aspecto formal; ${ }^{9}$ isto é, a uma tentativa de ordenar o múltiplo. A organização formal é, pois, um ente resultante de um processo de simplificação para efeito de comunicação. Em realidade, a organização se estabelece sobre o caos, sobre uma permanente transformação, um eterno devir, constituindo-se em um estado de fenômenos que está submetido à vida (ao devir). Por isso, ontologicamente, ela não é uma unidade estável (um ponto fixo, uma regularidade, uma identidade), mas uma contínua luta entre tentativas de estabilidade e instabilidade, uma eterna luta entre limite e transgressão. A ideia de organização associada ao princípio de duração (e não de devir) é uma ficção que oculta uma pluralidade de sentidos e forças abrigadas sob o rótulo "organização". Uma narrativa organizacional será sempre uma redução, pois a linguagem é sempre um meio de expressão simplificador da realidade..$^{10}$

Nesse sentido, a metalinguagem difundida pelo pensamento moderno construiu uma noção de razão que é excludente (MOSÉ, 2012). Buscar a verdade significa automaticamente excluir outros pontos de vista. A razão moderna se sustenta por um princípio de oposição/exclusão: para se estabelecer é preciso se confrontar com a não razão, com a falsa razão (a possibilidade do erro, da ilusão, da loucura, dos excessos) e excluí-la do discurso hegemônico. Evidentemente, o pensamento científico que emerge dessa concepção tem dificuldades de lidar com aspectos ligados ao plano da vida (afetos, instintos, corpo, erro, emoções etc.) e com a diferença (com o outro, com o outro lado da razão).

Mosé sugere que o nascimento da filosofia grega - na verdade, pode-se pensar no período pré-filosófico, pois a autora está falando de um tempo pré-socrático - é assinalado por uma rivalidade intelectual entre o pensamento vinculado ao devir (do vir a ser: o mundo é um jogo no qual todas as coisas carregam o seu contrário, ou seja, os opostos se autocompletam), que acredita na existência de um fluxo contínuo como fundamento de tudo o que existe (a essência da realidade é sua permanente transformação); e o pensamento vinculado ao ser, que crê na existência como duração,

\footnotetext{
${ }^{7}$ O sistema é a extensão da racionalidade humana (uma prótese), i. e., o desdobramento do sujeito moderno na teoria organizacional, conforme Cooper (1990).

8 "O homem está órfão de Deus porque acredita na imagem única e causal que faz de si mesmo e reivindica o lugar de princípio, de ordenação do mundo" (MOSÉ, 2012, p. 125).

${ }^{9}$ A organização que se estabelece mediante as orientações normativas, as decisões jurídicas, os comunicados "oficiais", os planos estratégicos formais, a hierarquia estabelecida normativamente, os atributos de porte, faturamento, performance etc.

10 "A linguagem, que é uma redução, uma simplificação do mundo por meio de signos, somente se tornou possível em função de nossa capacidade de ficção, mas esta capacidade criativa, inventiva foi esquecida e o mundo inventado foi tido como aquele que é, como essência, como verdade. Foi somente graças a sua capacidade de esquecer que o homem chegou a desenvolver a linguagem. Esqueceu a pluralidade, a mudança, o tempo e substituiu o mundo por um grupo de sinais, de signos. A linguagem, sustentada por um princípio de identidade, tornou-se a referência de duração que fundamentou a vontade de negação da vida e tornou-se a referência de realidade". (MOSÉ, 2012, p. 157-158)
} 
permanência e identidade, "momentos" alcançados somente pela via do pensamento. De um lado, Heráclito de Éfeso; de outro, Parmênides de Eleia. Para esse último,

[...] existe uma realidade absoluta, imutável, única, e ela é o Ser. O Ser é uno, único, contínuo, eterno. Tudo o mais é ilusão. [...].

Para Parmênides, o movimento existe para os sentidos, que se enganam, somente o pensamento pode perceber a verdade, o ser. A verdadeira realidade não está na experiência, mas no plano do pensamento. O pensamento é o único caminho para a verdade. (MOSÉ, 2012, p. 100-101)

Ainda com Mosé, pode-se dizer que a ideia de razão fundada por Parmênides se sustenta no princípio da não contradição, do não ser. A afirmação do ser reclama a negação do ser (o não ser); logo, a verdade se estabelece a partir da exclusão. Para Mosé, o pensamento do ser ganha preponderância sobre o pensamento do devir e é ele quem influência a filosofia grega nascente no século $V$ a.C. - sobretudo, a concepção platônica, mas também aristotélica -, bem como grande parte do pensamento filosófico ocidental, naturalmente sofrendo algum grau de transformação, mas sem perder essa identidade.

Para Platão,

[...] em algum lugar, em um mundo que não é esse que conhecemos e vivemos, existem essências, ideias puras, eternas e idênticas a si mesmas, que não podem ser acessadas pelos sentidos, mas pelo pensamento. Estas ideias são a fonte, o modelo, para tudo que o que se manifesta na natureza. A essência é o núcleo a partir do qual as variações podem ocorrer, ela define o desenvolvimento que uma coisa terá. Em outras palavras, este mundo é uma cópia imperfeita, uma sombra do verdadeiro mundo de coisas fixas, de essências, o mundo das ideias. O homem possui um corpo, que o vincula ao mundo das aparências e do erro, mundo das sombras; mas possui também uma alma, um espírito capaz de atingir as ideias puras, a verdade. Os homens devem então se desembaraçar destas aparências que os sentidos Ihe imprimem, que estão no domínio dos pseudos, e se dedicar à contemplação da alma, único caminho para a verdade. A contemplação do mundo das ideias, que se chama em grego theôria, permite ver a articulação das essências, revelando, acima de tudo, a ideia suprema, que ilumina todas as outras. (MOSÉ, 2012, p. 113-114)

Com efeito, essa noção de razão irá priorizar a busca pela necessidade dos conceitos e definições e pela universalidade dos mesmos: "Se existe um substrato que não muda, e que não pode ser apreendido pela sensação, senão pelo pensamento, então, está instaurada a possibilidade de definição, e a definição é o que deve ser buscado no conhecimento de cada ser, de cada essência" (MOSÉ, 2012, p. 117).

No rastro de Platão, Aristóteles "operacionaliza" a ideia de razão, que acabamos de mencionar, na elaboração de uma linguagem, que deve obedecer quatro princípios lógicos: (i) da identidade: algo só pode ser conhecido e pensado se for concebido e conservada a sua identidade; (ii) da não contradição: A é A e é impossível que seja, na mesma relação, não A; (iii) do terceiro excluído: ou Sócrates é homem ou não é homem, ele não pode ser e não ser homem ao mesmo tempo (iv) da causalidade: tudo é proveniente de uma causa (uma essência) e é a causa para alguma coisa. Uma das consequências desse pensamento filosófico é que "[...] a lógica para Aristóteles é ontológica, porque é o que permite a continuidade entre a linguagem e o ser. A articulação entre ser (como essência e verdade primeira) e linguagem faz com que, nesta concepção, exista uma perfeita adequação entre o conhecimento e o objeto" (MOSÉ, 2012, p. 118). A lógica é o único caminho para a verdade e a verdade é, pois, a exigência da vinculação entre pensamento e coisa (objeto). Aristóteles acredita que dotando a linguagem de fundamentos lógicos ele está criando um instrumento verdadeiro (não ficcional) e único para se acessar a verdade das coisas.

Dessa forma, ao sair do mundo "muito mais complicado" das sensações, a lógica, como um filtro, termina por se impor como um modelo excludente, um aparelho de filtragem que, ao pensarmos, faz com que simplifiquemos a multiplicidade e a diversidade dos acontecimentos, excluindo uma parte da vida, a que diz respeito ao corpo, aos corpos. 
O que a lógica, por princípio, exclui é o fluxo das sensações, das paixões. Por se fundamentar na linguagem, ela é o modelo primeiro de inserção e exclusão, e por isso mesmo serve de base para todos os outros modos de exclusão vigentes. Como Platão e Aristóteles não conseguiram se contrapor ao sofista, inventaram a categoria do "falso" e disseram: "Ele não deve ser ouvido, ele é o falso"; ou, então, o argumento do sentido: "O que ele diz é contraditório, e o que é contraditório não tem sentido". O que as argumentações filosóficas em torno da verdade permitiram foi a justificação da exclusão. O primeiro modelo excludente é o modelo da linguagem. Considerando a cena na qual a filosofia se deu, a lógica foi o armamento capaz de submeter o inimigo. Os sofistas, que assumiram a lógica como ficção, passaram para a posteridade como enganadores, ao contrário do lugar de honra dado a Platão e Aristóteles. (MOSÉ, 2012, p. 119-120)

Mosé (2014) comenta que a afirmação de inspiração nietzschiana de que a linguagem simplifica a realidade e sujeita os indivíduos, sendo, portanto, sempre uma redução simbólica, não decorre de uma mera arbitrariedade dos seres humanos. É, pois, uma necessidade orgânica: é somente pela redução do complexo ao simples, que o orgânico torna-se possível. Assim, a problemática em torno da linguagem não está na "descoberta" de seus aspectos ficcional e redutor, "[...] mas reside em estabelecer: que jogo de forças permitiu que esta simplificação fosse vista como modelo do bem, como verdade?" (MOSÉ, 2014, p. 90). O que torna importante avaliar é o jogo interpretativo (o campo de forças que representa a vida) que produziu a vontade de negar certas potências da vida (certas narrativas) em detrimento de um ideal de verdade. Por conseguinte, desvelar a verdade da realidade social passou a ser desvendar a pluralidade que a linguagem racional tenta encobrir.

O aspecto central que desejamos evidenciar é que o projeto do modernismo, especialmente, de sua variante sistêmica, aplicado na teorização e nas práticas organizacionais, construiu uma linguagem (textos, formas de expressão textuais, corporais, lógicas de pensamento etc.), apoiada na razão instrumental, que termina por reduzir as manifestações espontâneas do cotidiano, ou seja, a pluralidade e a potência que é a vida. O discurso moderno reprimiu a manifestação da força ativa/inventiva ${ }^{11}$ inerente à vida (COOPER e BURREL, 1988; MOSÉ, 2012; 2014), porque ele é de natureza referencial ${ }^{12}$, ou seja, aponta para uma racionalidade que transcende os fatos observados, como se houvesse, em algum lugar, uma resposta pronta para as situações, e o desafio fosse encontrá-la. Nesse sentido, ele é "instrutivo", pois sugere como agir em determinada situação e, ao fazer isso, aponta para um conhecimento que pretende ser menos dependente da história (do contexto e da situação), mais universal.

\section{O pós-modernismo e as organizações}

Os desconfortos em relação à tradição moderna "prepararam o terreno" para outro ponto de partida possível para a teorização organizacional: o discurso pós-moderno. A perspectiva pós-moderna enxerga o mundo em termos de paradoxos intrínsecos e de instabilidades provenientes do aspecto inventivo, ficcional e simplificador associados à linguagem. A organização formal é menos vista como um epifenômeno do planejamento e de uma ação voluntarista dos indivíduos e mais celebrada como uma reação a forças intrínsecas à vida social que ameaçam a estabilidade da vida formal organizacional.

\footnotetext{
${ }^{11}$ As ações ativas/afirmativas são compreendidas como ações espontâneas, agressivas, expansivas e vinculadas a forças que produzem novas interepretações e direções, como sugeriu Deleuze. As ações reativas são forças que tentam negar ou mesmo domesticar as forças ativas; são forças compensatórias, que tentam remediar as forças ativas (COOPER e BURREL, 1988). Um exemplo de pensamento reativo é a crença de que o ato de conhecer o mundo pode ser alcançado por meio da representação desse mundo, como se fosse possível criar uma linguagem que não "contaminasse" o nosso modo de conhecer.

${ }^{12}$ Peters (2000) faz um uso diferente desses termos. O autor apresenta o estruturalismo como uma tradição filosófica autorreferente (autônoma) e o pós-estruturalismo, o contrário. Imaginamos que isso ocorra, porque sua base de raciocínio é a ideia de sistema. Como o estruturalismo adota a noção de sistema como uma estrutura funcional, lógica, coerente (que não admite contradições ou que as contradições têm um "lugar certo" para acontecer), que deve operar eliminando-se as ambiguidades, Peters nomeia a ciência estrutural como um pensamento autônomo. O critério de Cooper e Burrel, quando afirmam que o modernismo (como já dito, os textos usam denominações diferentes para significados semelhantes) centra-se num princípio intelectual referente, é sua crença na noção de uma razão transcendental - existência de uma lógica soberana que está além da vida mundana. Para os autores, o pós-modernismo substitui a razão transcendental pela difference, que está ligada à potência da vida, como ficará claro na continuidade do artigo. Por isso, eles utilizam o termo autorreferente ou autorreflexivo. Essa nota serve, de fato, para lembrar que a polifonia é uma realidade na academia e que o(a) leitor(a) deve estar atento a esse fato, se sua intenção for estabelecer cruzamentos entre este texto e outras fontes sobre o assunto.
} 
Em linhas gerais, a narrativa pós-moderna crê que a realidade social possui existência independente da razão humana, isto é, ela rejeita a razão transcendental, que ocupa, nas tradições filosóficas de inspiração metafísica, uma espécie de "tribunal de arbitragem" dos comportamentos na sociedade. A razão é, logo, autorreferente: a realidade não é dirigida pelo homem, mas também não prescinde da força humana, ela apenas é, mencionam Cooper e Burrel.

No léxico pós-moderno, o sistema é uma projeção humana, assumida de modo não crítico, para afirmar a existência de um mundo que faça sentido para um indivíduo (ou um grupo) e o colocar no centro do controle. O pós-modernismo, por conseguinte, descentra a agência humana de sua posição de se considerar o centro da racionalidade da vida. Acentua que, como viventes, construímos interpretações (discursos) sobre o mundo e que tais interpretações têm status relativo. ${ }^{13}$ Afirma que a realidade construída a partir de formas de pensamento a priori (por meio de instruções normativas, jurídicas, por exemplo) não pode ser confundida com "a" realidade (com o mundo real), pois o mundo não "está lá", esperando por nós, intocado. O mundo é resultado de um processo complexo de "desejar conhecer" (will know), de sentir entusiasmo, raiva, de sofrer, de se apaixonar etc. Essas motivações organizam a experiência humana e configuram o que Nietzsche chamou de vontade de potência (MOSÉ, 2014), que confere ao ser humano uma ininterrupta capacidade interpretativa e, em especial, inventiva. Essas motivações ativas promovem o caráter transformacional da realidade (elas asseguram o devir).

O esforço moderno de criar uma realidade motivada pela ação racional e de fazer parecer que esse tipo específico de ação é um comportamento tipicamente humano, natural, é compreendido pelos pós-modernos como uma tática para sobrepor o formal (ou o normal, o dentro) ao informal (ou o anormal, o fora). Por tal razão, no pensamento pós-moderno, há uma tentativa de mostrar o extraordinário ocultado pelo ordinário (COOPER e BURREL, 1988). Esse movimento de revelar a emergência e o ocultamento dos saberes, dos discursos, é tipicamente um método pós-moderno, empregado claramente por Foucault e por Jacques Derrida, por exemplo, como lembram Cooper e Burrel.

Para Cooper e Burrel, a investigação pós-moderna focaliza a resposta nos problemas por uma via intelectual indireta (nome dado por nós); ou seja, interessa problematizar a lógica que sustenta as respostas e a formulação dos problemas. As respostas per se são simplificações da realidade, inversões temporárias do problema (como fica claro na análise que Cooper (1989) faz do trabalho etnográfico de Latour e Woolgar empreendido num laboratório científico. Adiante, na subseção "Repensando as organizações", retomaremos esse ponto). A análise da realidade social, portanto, deve partir do exame sobre como o pensamento está estruturado para gerar uma determinada solução.

O pensamento pós-moderno se assenta em alguns conceitos centrais, expostos na sequência, a fim de elucidar o debate modernismo e pós-modernismo e facilitar o entendimento de uma ontologia e epistemologia organizacionais vinculadas à segunda tradição filosófica em apreciação.

O primeiro deles é a crítica nietzschiana à "nostalgia da origem" (DERRIDA, 2002), que se sustenta na afirmação de que Ser não significa perder algo, afastar-se de uma essência arcaica, primitiva, natural, isto é, da pureza da presença. O "método" de Nietzsche (genealogia) é uma abordagem que não busca as formas puras e essenciais que preexistem a nossa experiência histórica, profana e cotidiana (COOPER e BURREL, 1988). Nietzsche acredita que na origem das coisas não existem formas puras ou verdades essenciais, perdidas ao longo do tempo, mas disparidades, diferenças, indeterminação, ou seja, o jogo da diferença (um campo de forças). O método nietzschiano, que inspirou Foucault, Lyotard, Derrida, Deleuze e Guattari, entre outros, nega a ideia de uma origem perfeita, em favor da existência de um processo de tensão diferencial ininterrupto, retratado pelo jogo da diferença.

O segundo conceito, intimamente relacionado ao anterior, é a noção de diferença (difference): um movimento de pensamento (uma forma, um modelo) autorreferente, no qual os termos - os discursos, os signos; enfim, a informação de modo geral, cf. Cooper (1990) - contêm sua própria "oposição" e, logo, recusam qualquer compreensão singular (única, autônoma) dos seus significados. ${ }^{14}$

\footnotetext{
${ }^{13}$ Para os pós-modernos, o discurso é menos um meio de representação da realidade que "está aí, dada" - embora também cumpra essa função - e mais um meio de construção de realidades e de subjetivação (COOPER, 1989; 1990; COOPER e BURREL, 1988).

${ }^{14}$ Conceituamos algo por aquilo que ele não é (COOPER, 1989; 1990). Por exemplo: só se sabe o que é civilização, a partir do que se entende por barbárie. Esses termos individuais habitam-se reciprocamente (COOPER, 1989). O significado decorre da mistura entre essas oposições, mas como esse processo é contínuo e inventivo, o significado é transitório, imprevisível e indeterminado.
} 
O pensamento pós-moderno admite que a diferença é constitutiva; ou seja, é o movimento contínuo de diferença que mantém a ação social, afastando-se da lógica moderna, que objetiva o estabelecimento do consenso. Para os pós-modernos, a pretensão moderna de buscar o consenso implica a destruição dos dissensos. O que se "perde" nessa operação (chamada de redução, simplificação, repressão, censura, etc.) deve ser o alvo das reflexões, como citado anteriormente. De fato, esse estado permanente de dissenso (a transgressão, o anormal) não pode ser compreendido isoladamente. Reiterar os dissensos como instâncias isoladas não parece ser o caminho da investigação pós-moderna: o dissenso deve ser entendido sempre em sua relação com o que se considera unidade (o homogêneo, o normal) e vice-versa. Há uma permanente tensão intrínseca à vida humana entre unidade e heterogeneidade ("desunity"). Esse deve ser o locus de investigação (COOPER, 1989; 1990; COOPER e BURREL, 1988). Essa tensão (diferença) que não cessa (uma força contínua, irredutível) é, em si, o que alimenta a vida. Ela é a realidade social. A diferença é concebida como um tipo de energia primordial que funda a vida, complementam Cooper e Burrel. É o que assegura a (auto)transformação permanente, o devir. Essa é uma visão (auto)reflexiva (ou autorreferente) da vida, que valoriza o plano do engajamento, do "aqui e agora", conforme retratado por Deleuze e Guattari (2011). ${ }^{15}$

A noção de diferença é central na teorização de vários pensadores ligados à crítica do modernismo. Neste artigo, focaremos nas contribuições do filósofo argelino, radicado na França, Jacques Derrida. Ele desenvolve a genealogia nietzschiana - também se inspira em outros pensadores, como, por exemplo, Martin Heidegger - e propõe um novo movimento de pensamento capaz de orientar nossa postura investigativa no mundo da ciência, que ele chamou de différance, conceito apropriado por Cooper (1989; 1990) para teorizar sobre as implicações do pós-modernismo na análise organizacional. Tal proposta epistemológica é um dos caminhos disponibilizados pelo pensamento pós-moderno para demonstrar que a racionalidade instrumental dominante nas teorias administrativas oculta o processo de contradição constitutivo da existência humana. A análise derridiana é focada no caráter processual das instituições (organizações, família, prisões etc.), como uma oposição à perspectiva estrutural. Ela mostra que o mundo da estrutura, aceito pelo senso comum, é produto de uma lógica que privilegia a unidade e a identidade. O pensamento humano tende à estrutura; caímos, frequentemente, na armadilha da estrutura, comenta Derrida (2002). Esse hábito mental dificulta a compreensão do caráter nômade e paradoxal da vida, e o propósito de Derrida é reverter esse vício intelectual, mostrando que o processo é anterior, e mais fundamental, que a estrutura (COOPER, 1989; COOPER e BURREL, 1988).

Por via de regra, entende-se que o pensamento assume um lugar privilegiado na subjetividade humana e que a linguagem é compreendida como veículo de expressão e transmissão desse pensamento. Derrida chama essa perspectiva de "logocentrismo". Nesse enquadramento, a racionalidade se sustenta a partir de um logos original ou um elemento metafísico (mente, alma, razão etc.) que valida e atribui significado às experiências. Em outros termos, acredita-se que existem forças extra-humanas (extramundanas) que dirigem o mundo social. O logocentrismo opera como um ponto fixo (um centro, uma essência) capaz de dirigir/corrigir a tendência errante do discurso. São permitidas variações, mas a partir desse centro comum (os excessos são possíveis, desde que a partir desse centro) (COOPER, 1989).

Derrida combate esse modo de pensar, cuja idade se confunde com o próprio nascimento da filosofia ocidental, por volta do século $V$ a.C. O leitmotiv de sua obra é mostrar o caráter ambivalente, múltiplo, relativo-complementar e redutor, latente em todo o discurso. Ambivalente, considerando autocontradições e dilemas internos, apontando para um campo de significados muitas vezes incompatíveis; múltiplo por admitir diversos significados; relativo-complementar pelo fato dos significados se autocompletarem em permanentes oposições; e redutor porque o significado é sempre uma imposição, dado que os termos são definidos em função de oposições. São esses aspectos que levam à falência da razão concebida como um princípio transcendental (cf. COOPER, 1989; 1990; COOPER e BURRERL, 1988; DERRIDA, 2001a; 2001b; 2002), Aplicado à análise organizacional, esse aforismo sugere que a organização abriga em si mesma o que a transgride, ou seja, a desorganização. ${ }^{16}$ Esse é o ponto-chave para Robert Cooper (cf. COOPER, 1989; 1990). Ele ficará ainda mais claro, na medida em que avançarmos nas ideias de Derrida.

\footnotetext{
${ }^{15}$ Para a dupla de filósofos, a vida é imaginada como uma multiplicidade de forças acionadas na experiência, naquilo que chamaram de plano de consistência/imanência ou ainda de corpo sem órgãos ( $\mathrm{CsO}$ ). Nessa concepção, valoriza-se o engajamento no mundo como um devir criativo e como um momento de afetação (de interação, de mistura) com o outro no espaço.

${ }^{16}$ Cooper (1990) nomeou esse estado de "nível zero de organização" (estado de nenhuma ordem/organização específica), inspirado, parcialmente, na ideia de Lévi-Strauss de "valor/nível zero". Da forma proposta por Cooper, ele deve ser compreendido como semelhante ao princípio de différance. Diz Cooper (1990): nível-zero é, portanto, uma condição teórica de nenhum significado, nenhuma forma, de desordem absoluta, que podemos chamar de
} 
O entendimento da linguagem como um sistema de différance guarda uma aproximação parcial com a concepção estruturalista do linguista suíço Ferdinand de Saussure (COOPER, 1990; DERRIDA, 2001b). ${ }^{17}$ Para Derrida, o movimento da différance - união entre as palavras francesas differ e defer (COOPER, 1989; 1990) ${ }^{18}$ - sugere que o significado de qualquer palavra ou frase é derivado do processo de diferimento em relação a outras palavras ou frases. Seu pressuposto central é a crítica ao pensamento tradicional (logocentrismo) que entende o sentido como presença: o vocábulo "presença" remete a uma operação cognitiva que crê na conceituação de um elemento em si mesmo, como se o próprio elemento possuísse um fundamento, uma substância; enfim, um princípio que remeta apenas a si mesmo (DERRIDA, 2001a; 2001b). Questionar esse pressuposto é o alvo principal do filósofo ao sugerir que o processo de significação ocorre através de um encadeamento de significados, que ele chamou de rede de significações, texto, escritura ou, ainda, simplesmente de rede.

Seja na ordem do discurso falado, seja na ordem do discurso escrito, nenhum elemento pode funcionar como signo [significante + significado] sem remeter a um outro elemento, o qual ele próprio, não está simplesmente presente. Esse encadeamento faz com que cada "elemento" - fonema ou grafema - constitua-se a partir do rastro, que existe nele, dos outros elementos da cadeia ou sistema. Esse encadeamento, esse tecido, é o texto que não se produz a não ser na transformação de um outro texto. Não existe, em toda parte, a não ser diferenças e rastros de rastros. (DERRIDA, 2001b, p. 32)

Derrida (2001b, p. 33) complementa:

O grama como différance é, pois, uma estrutura e um movimento que não se deixam mais pensar a partir da oposição presença/ausência. A différance é o jogo sistemático das diferenças, dos rastros de diferenças, do espaçamento, pelo qual os elementos se remetem uns aos outros. Esse espaçamento é a produção (o $a$ da différance indica essa indecisão relativamente à atividade e à passividade, aquilo que não se deixa ainda ser comandado e distribuído por essa oposição), dos intervalos sem os quais os termos "plenos" não significariam, não funcionariam.

Ao propor o princípio da diferença como uma lei predominante que orienta o processo de significação - e que, como revela a citação, consiste, ao mesmo tempo, em uma "estrutura e um movimento", ou seja, em uma interação entre ambos, que privilegia o movimento ${ }^{19}$-, Derrida quer dizer que nenhum elemento é capaz de fornecer, de modo independente isto é, pela via da presença - um significado, "[...] a não ser remetendo-o a um outro elemento, passado ou futuro, em uma economia de rastros" (DERRIDA, 2001b, p.35). Para pensar em termos de différance, será preciso renunciar “[...] à episteme que tem como exigência absoluta, que é a exigência absoluta de procurar a origem, o centro, o fundamento,

fonte primária da forma ou organização, se o conceito de "primário" e "fonte" não forem entendidos como uma origem absoluta previamente organizada, como acreditava Lévi-Strauss. Derrida (2002) cita que Lévi-Strauss sempre esteve atento à ideia do jogo da suplementariedade e à crítica da existência de um significado essencial, originário (ver Ibidem, p. 240-246), embora sobre esse último aspecto a posição do etnólogo francês seja assinalada por uma ambivalência, pois ao privilegiar a estrutura (a duração), em detrimento da história, Lévi-Strauss introduziu a noção de acaso/descontinuidade histórica como um fenômeno que representa um sistema original, que não obedece à lei das transformações: "Por exemplo, a aparição de uma nova estrutura, de um sistema original, faz-se sempre - e é a própria condição da sua especificidade estrutural - através de uma ruptura com o seu passado, a sua origem e a sua causa. Só se pode portanto descrever a propriedade da organização estrutural não levando em conta, no próprio momento dessa descrição, as suas condições passadas: omitindo colocar o problema da passagem de uma estrutura para outra, colocando entre parênteses a história. Neste momento 'estruturalista', são indispensáveis os conceitos de acaso e descontinuidade” (Derrida, 2002, p. 247). O conceito de “imediaticidade interrompida” (DERRIDA, 2002, p. 248) representa no pensamento de Lévi-Strauss “[...] uma espécie de ética da presença, de nostalgia da origem, da inocência arcaica e natural, de uma pureza da presença e da presença em si na palavra; [...]” (DERRIDA, 2002, p. 248), isto é, de um termo que não comporta nenhum caráter diferencial, diferente de todos os outros que adquirem sentidos pelo movimento de suplementariedade (DERRIDA, 2002).

${ }^{17}$ Derrida (2001b) cita que Saussure entende a linguagem como um sistema, que vê o signo como um efeito da diferença. Sobre as aproximações e distanciamentos entre Derrida e Saussure, ver Goulart (2003) e Lima (2009).

${ }^{18}$ A palavra différance incorpora os dois significados do verbo francês differer: adiar no tempo e diferir no espaço. Significa que a natureza diferencial das palavras não pode ser compreendida como uma singularidade e que o seu significado sempre tem que ser "adiado", há uma ausência contínua (COOPER, 1989; 1990).

${ }^{19}$ A rigor, Derrida não abandona, por completo, o conceito de estrutura, "apenas" não confere o mesmo status que o programa estruturalista Ihe atribui. Sua proposta é exatamente o inverso, enxergar a estrutura como um acontecimento (uma ruptura, um redobramento): “[...] a estruturalidade da estrutura, embora tenha sempre estado em ação, sempre se viu neutralizada, reduzida: por um gesto que consistia em dar-Ihe um centro, em relacionála a um ponto de presença, a uma origem fixa. Esse centro tinha como função não apenas orientar e equilibrar, organizar a estrutura - não podemos efetivamente pensar uma estrutura inorganizada - mas sobretudo levar o princípio de organização da estrutura a limitar o que poderíamos denominar jogo da estrutura." (DERRIDA, 2002, p. 230) 
o princípio etc." (DERRIDA, 2002, p. 241). Em decorrência da falta do centro, atua o movimento da différance, que é o movimento da suplementariedade (denotado na citação anterior pela palavra espaçamento): "Não se pode determinar o centro e esgotar a totalização porque o signo que substitui o centro, que o supre, que ocupa o seu lugar na sua ausência, esse signo acrescenta-se, vem a mais, como suplemento" (DERRIDA, 2002, p. 241). A différance é sempre suplementar, pois acrescenta um significado. É esse excedente de significado, que coloca o sistema em movimento. Ele é propriamente a produção viva permanente na fala, chamado de fala viva. A "escritura-como-suplemento" influencia todos os atos da fala (WOLFREYS, 2009). ${ }^{20}$ Desse modo, quando a fala ocorre, há uma desunião - Derrida faz referência à noção de espaçamento, de deslocamento como substituição, como adição e, por conseguinte, como suplemento - do significante e do significado. Segundo Wolfreys (2009), Derrida chamou essa desunião de brisura, representando uma rachadura, fragmento, ruptura, que possibilita o significado.

Cooper (1989) interpreta o jogo da différance do seguinte modo: o pensamento logocêntrico compreende a diferenciação inerente à construção de significado em termos de oposições binárias hierarquizadas. Nessa ótica, são enfatizados os dois termos separadamente, embora se reconheça a relação entre eles. $O$ pensamento da diferença, como a concebe Derrida, insiste que a oposição/divisão/classificação seja vista não como um ato de separação per se, mas como um ato de indiferenciação em que os termos são mantidos juntos. Assim, a divisão (que cria e assinala a diferença) separa e junta, simultaneamente. $\mathrm{O}$ foco recai para a motivação dessa operação de afastamento e aproximação. Paradoxalmente, é a percepção de afastamento que cria a relação de unidade. Desse modo, Cooper coloca que a diferença é um compartiIhamento do paradoxo entre dois termos, alimentado por um contínuo processo de diferenciação. Para enfatizar a natureza processual dessa concepção, como um traço totalmente distinto da diferença como presença, que admite a existência de significados per se - chamada por Cooper (1989) de diferença estática -, Derrida propõe o termo différance.

Diz Derrida (2002) que todo sistema de conceitos criado a serviço da ciência, que ignorar o processo de différance, fazendo crer na existência de uma lógica única, universal, natural ao homem e no sentido como presença, está destinado a colocar no espaço do impensado o que o torna possível, a saber: os sentidos excluídos e a motivação de sua exclusão. Ou seja, para Derrida a separação per se entre termos opostos não existe; há, de fato, uma coexistência. Quando se enxerga esses termos como opostos, como termos que não se misturam (como diferenças que podem até interagir, mas que não se interpenetram, que não se deixam atravessar), tende-se a produzir um pensamento que separa as noções de "dentro" e "fora" (por exemplo, o ambiente interno como o "lado de dentro" da organização e o ambiente externo, sendo o "lado de fora" da organização), de indivíduo e sociedade etc. ${ }^{21}$ Não há nada dentro e fora da organização (no sentido de uma verdade absoluta). Essa separação é fruto de uma perspectiva epistemológica - de uma ilusão epistemológica, cf. Cooper (1990) - que entende esses termos como opostos, como irredutíveis. No entanto, seguindo uma postura pós-moderna,

\footnotetext{
${ }^{20}$ Gergen (1994) coloca como exemplo a frase: "Sejamos lógicos sobre isso, o resultado final seria o fechamento da divisão Portsmouth". Essa frase não traz um sentido claro (e único) para todos os leitores, não existe um sentido interno, independente do leitor (por isso uso da palavra differ no conceito de différance). Seu significado depende do que cada leitor compreende por "lógico", "resultado final" e "fechamento". E mais: para extrair tais significados, o leitor fará referência a outras palavras (por isso, o uso da palavra defer no conceito de différance), como, por exemplo, relacioná-la ao sentido das palavras "racional", "sistemático" ou "coerentes", entre outras. E ao acionar, como falante, uma dessas extensões de significados - por exemplo, a palavra "racional" - para entender a palavra "lógica", novamente, ativa-se o sistema de différance. Assim, o significado de um termo segue o rastro de vários outros. A isso, Derrida chamou de cadeia de significações ou rede de significações.

${ }^{21}$ Acreditamos ser incorreto dizer que o pensamento moderno não considera, em sua formulação central, a ideia de relação e diferença. $\mathrm{O}$ artigo de Cooper e Burrel (1988) demonstra claramente como esse par está presente nas teorizações modernas manifestadas, majoritariamente, no campo da administração por propostas estruturalistas. O estruturalismo é conceituado em termos de uma relação, que é funcional, e uma diferença, que é posicional (LEFEBVRE, 1967; PETERS, 2000). Naturalmente, é no tratamento dado a esses conceitos que ambas as perspectivas se distanciam. Stuart Hall nos lembra que o olhar sociológico (da sociologia como disciplina que se consolida na primeira metade do século XX, sob inspiração moderna) se define pelo esforço em localizar o indivíduo em processos de grupo e constrangido por normas coletivas. Nessa perspectiva, a sociologia fornece um contraponto ao individualismo racional da lógica cartesiana. No entanto, o dualismo típico do pensamento cartesiano - a separação entre indivíduo e sociedade e seus afins: natureza e cultura, sujeito e objeto, sujeito e mundo, mente (individualidade) e corpo (espacialidade) etc. - foi mantido. A perspectiva clássica do sujeito sociológico considera a identidade como algo que emerge (ou que preenche a) da relação eu-mundo, compreendendo que há uma internalização do exterior pelo sujeito e uma externalização do sujeito no exterior, através da ação social. Portanto, permanece a ideia de um interior e exterior. Na perspectiva pós-moderna, não existe um "eu-coerente", formado a priori e que se modifica à medida que se confronta com o mundo. A ideia de um interior e exterior é compreendida pelos pós-modernos como ilusões epistemológicas, pois se crê na fusão entre o ser e o ambiente ao seu redor (entre natureza e cultura, entre indivíduo e sociedade, entre o eu e o outro etc.). Nesse enquadramento, a existência de um eu é provisória e situacional. Se um indivíduo não se "desintegra" totalmente não é porque ele seja unificado por um sentido coerente de si, mas porque, em certas circunstâncias, diversas facetas identitárias podem ser construídas/acionadas e, em seguida, articuladas de um modo mais conveniente e possível naquela situação (HALL, 2006). A perspectiva moderna privilegia um sentido para o relacional e a diferença, que não admite a interpenetração das partes.
} 
eles são redutíveis entre si, eles se retroalimentam perpetuamente, produzindo-se, e o que chamamos de "dentro" e "fora" é sempre fruto de um julgamento cultural. É esse aspecto que Cooper procura enfatizar.

Imaginamos ter ficado claro que a linguagem opera como um sistema de diferenças que produz significados ambíguos, imprecisos. Por tal razão, é frequente observarmos pensadores da escola desconstrucionista sugerindo que os significados estão "soltos" (free floating), isto é, não estão vinculados a um significado fixo ou a uma posição fixa, e por isso podem mover-se livremente (decorre daí o caráter ficcional da linguagem, afirmado pelo pós-modernismo). De fato, essa afirmativa é verdadeira se for examinada com parcimônia. É prudente recorrermos ao próprio Derrida (2001b, p. 33-34), a fim de que sua posição teórica não seja identificada com um relativismo radical e com a própria negação da história:

A atividade ou a produtividade conotadas pelo $a$ da différance remetem ao movimento gerativo no jogo das diferenças. Essas últimas não caíram do céu nem estão inscritas de uma vez por todas em um sistema fechado, em uma estrutura estática que uma operação sincrônica e taxonômica pudesse esgotar. As diferenças são os efeitos de transformações e, desse ponto de vista, o tema da différance é incompatível com o motivo estático, sincrônico, taxonômico, a-histórico etc. do conceito de estrutura. Mas não é evidente que esse motivo não é o único a definir a estrutura e que a produção das diferenças, a différance, não é a-estrutural: ela produz transformaç̧̃̃es sistemáticas e regradas, que poderão ser capazes, até certo ponto, de dar lugar a uma ciência estrutural. O conceito de différance desenvolve, inclusive, as exigências de princípio mais legítimas do "estruturalismo".

Ou seja, as "diferenças" não "caem do céu", mas também não estão circunscritas a um sistema fechado que reclama a existência de uma essência/centro. Derrida complementa: o jogo da différance não é a-estrutural, ele produz repetições, mas essas não devem ser confundidas com o estado natural da vida; esse é ponto enfatizado pelo filosófo. Como dito (ver nota de rodapé 19), deve-se pensar na estrutura como um acontecimento. Em outros termos, é necessário acrescentar movimento no pensamento "estático" do estruturalismo.

Gergen (1994) interpreta essa questão do seguinte modo: na prática, os significados são soltos, mas circunscritos por uma realidade social. O falante produz o discurso (também impreciso), mas um significado suplementar/complementar é necessário para determinar seu sentido: é quem ouve que acrescenta esse complemento. Os discursos acessados por cada indivíduo têm um significado próprio, não havendo indivíduos que atribuam o mesmo significado. ${ }^{22}$

Cooper (1989) tem um entendimento interessante sobre a suplementariedade derridiana. Ele sugere que o suplemento de significado está associado ao excesso de significado, ao exterior, ao lado de fora, à desorganização etc.; enfim, aos aspectos indesejados da realidade social (o "lado B" da realidade social). Como vimos, a différance trabalha seguindo o princípio da coexistência de "opostos". Portanto, tais aspectos indesejáveis desempenham um papel necessário para a conceituação daquilo que pertence ao interior (a essência, a duração, a organização etc.). Assim, o exterior, longe de ser uma mera oposição, é uma característica necessária para o lado de dentro. Nessa perspectiva, o exterior é uma característica ontológica do sistema social, pois ele desdobra/desloca o interior. A proposta derridiana não se resume a dizer que os termos de um discurso são ambivalentes (admitem várias interpretações, inclusive, contraditórias), diz Cooper. O insight de Derrida, complementa o autor, é estabelecer uma ontologia social a partir da interação entre esses vários significados. Os sentidos antitéticos dos termos convivem, coexistem e são responsáveis pela formação de significado. Essa convivência afasta a possibilidade de existência de uma razão transcendental que tenha um valor de verdade por si só (COOPER, 1989).

Outra implicação do pensamento de Derrida explorada por Cooper (1989) consiste em enxergarmos os conceitos como espaço, contraste, organização etc. não como propriedades naturais das coisas, pois eles são atributos produzidos pela différance e, como tal, não possuem uma "localização" específica (isto é, não são compreendidos como uma presença intrínseca). Inspirado nessa perspectiva, é que se pode pensar na crítica às divisões "dentro" e "fora" e outras similares,

\footnotetext{
22 "Mais concretamente, isso equivale a dizer que os gestores não são, nunca, racionais [no sentido da razão metafísica]; seus discursos são, de modo algum, capazes de apresentar um exímio julgamento ou serem realísticos" (GERGEN, 1992, p. 220). Ou seja, sua racionalidade (no sentido de procedimentos específicos para conhecer, i. e., um modo de pensamento) depende da interpretação de seus colegas, sendo, portanto, situacional e transitória. "Racionalidade, é, acima de tudo, um produto da colaboração social" (GERGEN, 1992, p. 220).
} 
como já comentado. Isso significa que não podemos falar nos objetos como se estivessem "dentro" de nossa mente, pois a mente "possui" apenas processos de différance, ou seja, a mente consiste nos próprios agenciamentos da différance, conjectura Cooper. Para Derrida (1978, p. 226), não existem ideias na mente (como se a mente fosse um contêiner): "nós somos escritos somente quando nós escrevemos, por meio de uma agência em nós, que sempre vigia nossa percepção". (COOPER, 1989, p. 490)

Um último apontamento feito por Cooper, é que a "escritura" é impensável sem repressão, que sua condição de possibilidade passa por uma negociação permanente entre censura e rompimento da censura (inventividade/espontaneidade) e que, por isso, ela é sempre paradoxal (COOPER, 1989). O paradoxo da agência humana reside no fato de que o indivíduo está, permanentemente, sob uma força de censura, que o obriga a ser, ao mesmo tempo em que possui a capacidade criativa de se inventar permanentemente. Censura e invenção estão em igualdade ontológica: o próprio processo de censura, por meio da différance, é um ato de criação, de dissimulação. Portanto, a visão de um sujeito autocentrado, autônomo e racional, é apenas um efeito do processo de différance. A agência humana é pensada em termos de um campo de forças - que constrange e permite novas ações -, acionado quando se vivencia as situações cotidianas. Dessa forma, o agente humano (como "escritor", como o agente da "escritura") se reproduz e é reproduzido pelo ato da escritura.

O primeiro passo na análise do mundo social é reconhecer isso como um modo de "lançar luz" à realidade e em quem somos. Para Kant, a razão que esclarece (enlightement) é proveniente de um modo normalizado de pensamento crítico (COOPER e BURREL, 1988). Para Cooper e Burrel (1998), inspirando-se em Foucault, é a experiência do acontecimento, do insight espontâneo, quando alguém é capturado por um poder além do racional/intencional, isto é, pela experiência aurática, que transita no plano do impensado, das ações não intencionais.

Cooper e Burrel, citando Nietzsche, sugerem que o corpo é o agente/meio (organ) da diferença, produzindo uma experiência aurática, isto é, uma experiência humana mais próxima da autenticidade, ${ }^{23}$ que o pensamento operatório/instrumental não é capaz de alcançar. A dimensão aurática sugere uma inversão no modo como interpretamos a realidade. A experiência humana aparece como uma manifestação de "estranhamento", na qual o normal e o familiar são vistos num lugar "fora do comum", como um modo desviante de ser. O modo normalizado de pensamento passa a ser o anormal, pois ele oculta as tensões "por trás" do familiar. Esse é um modo de pensar afirmativo e não reativo. ${ }^{24}$

\section{Repensando as organizações}

Antes de melhor organizar as ideias expostas até aqui, gostaríamos de comentar a análise de Cooper (1989) da etnografia de Bruno Latour e Steve Woolgar sobre a organização social do trabalho científico num laboratório americano de neuroendocrinologia, para exemplificar como a lógica de produção do conhecimento acadêmico permanece vinculada ao logocentrismo criticado por Derrida.

Latour e Woolgar (na interpretação de Cooper) descrevem que o saber científico é elaborado por meio de uma transformação do conhecimento descoberto no laboratório (no "chão de fábrica" da pesquisa) em informações que atingem a forma de "produto intermediário" dessas descobertas. Nesse momento, são produzidos gráficos, diagramas, relatórios etc., e os experimentos práticos ganham uma primeira materialidade na forma de dispositivos de escrita. A partir de então, algumas declarações científicas - por sua aceitação na comunidade acadêmica, devido a um suposto poder explicativo dos fatos analisados e, também, por questões políticas - são tomadas como teorias. Nesse instante em que as ideias são propagadas através de comunicações científicas, como os artigos, a base da produção científica (os "fatos descobertos" no laboratório) é colocada em segundo plano (há uma tentativa de apagar os vestígios da produção científica). Duas operações cognitivas animam esse estratagema: (i) a fragmentação do conhecimento científico (ainda no estágio de produto intermediário da ciência); e (ii) a inversão do conhecimento científico. No primeiro movimento, "fatia-se" o conhecimento e são criados objetos de estudo que têm sua relação com o todo enfraquecida. A partir daí, fala-se cada vez mais sobre o objeto, mas não do processo que consagrou sua existência. Em seguida, há uma inversão no

\footnotetext{
${ }^{23}$ Uma experiência marcada pela busca de maior complexidade e não de essencialidade.

${ }^{24}$ Sobre o conceito das palavras afirmativo/ativo e reativo, ver nota 11.
} 
pensamento: toma-se o objeto como o ponto de partida da pesquisa e as pressuposições e o contexto que o geraram tornam-se consequências/efeitos da pesquisa.

No processo de tradução do conhecimento gerado no "chão de fábrica" para as primeiras impressões escritas ("produto intermediário"), o objeto de pesquisa é compreendido como uma virtualidade que emerge dos fatos empíricos. No estágio posterior, em que as impressões escritas são transformadas em teorias acadêmicas ("produto final"), o objeto torna-se a razão pela qual as afirmações científicas foram construídas. Isto é, as afirmações científicas (as teorias) tornam-se espelho do objeto que "já estava lá", aguardando que os cientistas - com seus métodos "neutros" - o descobrisem. Cabe observar que o objeto é tomado como uma referência primária, que pode, simplesmente, ser (re)apresentado por um modelo ou teoria. Em ambos os estágios (produção do conhecimento intermediário e final), a escrita acadêmica procura minimizar a subjetividade e os aspectos contingenciais, em favor da objetividade e da estabilidade (COOPER, 1989). Por fim, o objeto de investigação científica foi construído, elimando-se os aspectos subjetivos, as incertezas, os possíveis suplementos/complementos de significados (a indeterminação de significados), no léxico de Derrida.

Em resumo, podemos dizer que a hipótese lançada por Latour e Woolgar, na década de 1970, é a de que os fatos científicos são "fabricados" pelas teorias; ou seja, ignora-se que as teorias são discursos edificados sob o jogo da différance e que, portanto, serão, sempre, "verdades" parciais ou narrativas ficcionais.

Em seu outro livro sobre os estudos científicos - A esperança de Pandora - Latour (2001) reafirma sua hipótese de que o cientista "faz" o fato mas que ele não está no comando, sendo surpreendido pela ação, da mesma forma que "aquilo" (o conhecimento/fato) que age por intermédio do cientista, também é surpreendido pelo que ele faz. Para Cooper (1989), Latour e Wolgar reforçam a afirmativa, sugerida por Derrida, de que, ao mesmo tempo em que escrevemos a nossa vida, somos escritos por ela; isto é, nossas decisões são fruto de uma mistura de repetição e invenção, ativada quando agimos. Esse é o grande paradoxo que fundamenta a nossa existência, a existência de nossas instituições e a produção de conhecimento.

O que essa reflexão tem a ver com as limitações da perspectiva moderna aplicada à teorização organizacional e como ela pode auxiliar na proposição de uma visão "alternativa", inspirada nas observações pós-modernas? Acreditamos que a organização formal que emerge do processo de construção científica de inspiração moderna adquire aspectos de linearidade, de causalidade, de finalidade, não por essas características serem inatas à organização - como se fossem resultados de um saber neutro, que não acrescenta significados ao ato de conhecer. Essas qualidades são resultantes de um olhar ex post facto (ver MANNING, 2008), que suprime uma multiplicidade de incertezas, tensões e contingências que caracterizam a organização real. O caráter ordenado do mundo não diz respeito ao seu aspecto ontológico ("a" verdade do mundo), mas a um efeito da différance, a uma forma possível de representação ${ }^{25}$ desse mundo. A análise de Latour e Woolgar revela que a suposta "referência primária" da representação é, realmente, uma construção que emerge por meio da escrita científica e que, por tal característica, vem depois dessa última e não antes, como a lógica da representação nos faz crer (COOPER, 1989).

Ao desvelar o caráter ficcional da produção científica, Latour (2001) entende que seu projeto consiste em dar mais realidade à ciência e não o contrário. Olhar o mundo de um modo mais complexo implica considerar criticamente a atitude de conhecer. Esse também é o nosso propósito. A questão que interessa enfatizar neste artigo, é que o objeto das análises tradicionais é a organização formal, isto é, a organização canônica, "politicamente correta" (proper), oficial, normativa e declarada publicamente (COOPER e BURREL, 1988). Um dos problemas dessa postura é não enxergar a organização formal como um modelo possível de representação da organização real, mas enxergar a organização como uma cópia "fiel" da realidade (COOPER, 1989). A organização é estudada como um objeto previamente constituído e não se observa as práticas que a constroem diariamente; ou seja, seu caráter processual (sua força viva!) é omitido.

Nesse sentido, a proposta de Cooper para a análise organizacional é desconstruir as abordagens representacionais, revelando a ligação entre o modelo representacional (a organização formal) e o mundo real da qual ela emergiu (a "desorganização" ou as "desorganizações"). Em Cooper (1990), esse projeto aparece elaborado do seguinte modo: enquanto

\footnotetext{
${ }^{25}$ Todo ato de conhecer é uma representação (CLEGG e HARDY, 2010). A representação do mundo ocorre por meio de processos sucessivos de diferenciação, selecionando e excluindo certas características. Nessa operação, o pensamento humano frequentemente ilude-se com o processo de mediação, de modo a crer que os símbolos dão um acesso não mediado (direto) ao mundo, sem uma intervenção seletiva. Esse processo de mediação funciona como uma metalinguagem, ou seja, o que se "vê" não é realmente a vida social, é um caminho para falar sobre ela. Assim, a metalinguagem é uma forma de representação que oculta ou ressalta os fatos, agindo como uma janela mental transparente que direciona a percepção humana (COOPER, 1990).
} 
nas ciências sociais o conceito de sistema como um padrão de relações adquire um status hegemônico, o que menos se problematiza/investiga é a motivação/natureza dessas relações. Toda relação implica uma divisão, em um dentro e fora, por exemplo. Com efeito, frequentemente, assume-se uma visão nepotista dos sistemas sociais. É preciso reverter essa situação, focalizando as relações, que, em última instância, são discursos responsáveis por construir identidades, categorias etc. Os estudiosos do fenômeno organizacional devem ater-se à tensão entre a organização e sua desorganização, complementa o autor. Para Cooper, um dos pontos fundamentais de uma interpretação pós-moderna das organizações é reconhecer que todo o discurso traz consigo o seu "oposto": a organização formal é continuamente seguida pela desorganização. $\mathrm{O}$ caráter desorganizador refere-se àquilo que ameaça transgredir o normal/formal, refere-se à ação local e imediata que ameaça a racionalização administrativa imposta pela estrutura normativa. Representa, pois, a força ativa da vida, a vontade de potência a que Nietzsche se refere (COOPER e BURREL, 1988; MOSÉ, 2012; 2014).

A organização (formal) é caracterizada pelo esforço contínuo de suprimir/censurar seu oposto, a desorganização. A tarefa do pensamento pós-moderno é expor essa operação de censura (censoring function) e mostrar que a desorganização constitui a organização e vive-versa (os discursos "opostos" representam, na verdade, dois lados da mesma moeda). Para tanto, sua recomendação (cf. COOPER, 1989; 1990; COOPER e BURREL, 1988) é que a pesquisa se concentre na micrológica, isto é, na observação cotidiana dos fatos organizacionais. As organizações não são um ente que preexiste, e a partir delas são estabelecidas relações sociais, "[...] elas ocorrem/sucedem/acontecem [occur] nessa lacuna existencial que se encontra além do discurso estabelecido [knowledgeable discourse]" (COOPER e BURREL, 1988).

A organização, longe de ser efetivamente dirigida pela lógica da eficiência, é erguida sobre (i) "truques/manobras/malabarismos" - acontecimentos inventivos que surpreendem o previsto e acentuam o caráter emergente da realidade social (tradução da expressão sleight-of-hand) -; (ii) visões agonísticas - manifestaçoes distintas, que se complementam; ${ }^{26}$ e (iii) "origens vergonhosas", isto é, origens mesquinhas, inconfessáveis (tradução da expressão latina pudenda origo). Esse é o grande insight pós-moderno para se pensar as teorizações organizacionais, afirmam Cooper e Burrel (1988). As organizações, sendo objetos empíricos, prosseguem vivas, ativas, híbridas e fragmentadas. Como diria Latour (1994), jamais fomos modernos, tampouco, nossas organizações o foram ou são.

\section{REFLEXÕES FINAIS}

Como visto, para Robert Cooper, as teorias tradicionais da administração representam uma "imposição" epistemológica cuja função é atribuir um significado possível à organização diante de uma infinidade de significados que a organização real - como uma instância da vida -, de fato, possui. Tais teorias apoiam-se num ideal de duração, de estabilidade, de essência, abrindo mão da pluralidade, do devir, da transformação, da ambiguidade como princípio ontológico. As ideias de Derrida proporcionam, para Cooper, um meio de questionar a visão hegemônica formalista da organização e mostrar como os aspectos racionais e estáveis são acompanhados "de perto" por desvios e contingências. A organização formal que emerge das teorias administrativas ligadas às tradições modernas é uma ficção que atende a propósitos bem específicos de poder, de exigência de performatividade, de crescimento e de controle sociais, representando, pois, uma imagem precária do mundo organizacional.

Nesse sentido, cabe ainda uma importante observação. A nosso ver, as contribuições de Cooper para a teorização organizacional não invalidam, por completo, os conhecimentos vinculados ao modernismo, mas chamam a atenção para as limitações e para o comprometimento ideológico dessas teorias. Concordamos com a crítica de Reed, quando ele afirma que:

Enquanto a análise pós-modernista está correta em sua rejeição de uma base cognitiva ou epistemológica universal para justificar nossa pretensão de conhecer, ela está profundamente equivocada em sua inferência lógica derivada dessa verdade; que a rejeição do fundamentalismo ou universalismo deve inevitavelmente levar a uma aceitação - até mesmo uma celebração - de uma forma extrema de relativismo político e epistemológico no qual o conhecimento científico social está totalmente absorvido num "discurso de poder" e nas práticas de controle que o legitimam. (REED, 1994, p. 178)

\footnotetext{
${ }^{26}$ Numa relação agonística as partes (ou os discursos) não são percebidas como adversários intratáveis que precisam se destruir reciprocamente mas como perspectivas contrárias combatidas mutuamente, embora se reconheça o direito de defendê-las (MIGUEL, 2014). A ideia, nessa qualidade de relação, é que permanece uma diferença irreconciliável, não redutora em uma convergência, que termina por apagar a diferença.
} 
Também concordamos com a sensata observação de Bruno Latour:

Todo o velho problema da correspondência entre palavras e mundo surge de uma simples confusão entre epistemologia e história da arte. Tomamos a ciência por uma pintura realista, supondo que ela proporcionava uma cópia exata do mundo. As ciências fazem mais que isso - pinturas também, no presente caso. Ao longo de etapas sucessivas, vinculam-nos a um mundo alinhado, transformado, construído. Nesse modelo, perdemos a semelhança, mas há uma compensação: apontando com o indicador para os traços de uma figura impressa no atlas, podemos, graças a uma série de transformações uniformemente descontínuas, estabelecer um laço com Boa Vista [cidade de Boa Vista, onde o autor esteve como pesquisador]. (LATOUR, 2001, p. 96)

Certamente, existem perdas e ganhos no processo histórico de construção de um campo de conhecimento. Entendemos que Cooper nos estímula a transitar nesse limiar. Essa postura crítica leva-nos a compreender as organizações como um fenômeno político em permanente transformação, dependente não apenas do contexto histórico, mas de situações ordinárias. Essa perspectiva está presente em Schatzki (2005), quando sugere que o locus analítico dos pesquisadores organizacionais deve ser o site de acontecimento das organizações. Portanto, acreditamos que uma visão das organizações como elas acontecem (cf. MIETTINEN, SAMRA-FREDERICKS e YANOW, 2010; SCHATZKI, 2006), isto é, das organizações como uma multiplicidade de processos (multiníveis) no "aqui e agora", ligados a uma história e a uma ideologia, é a mais adequada para entender as práticas organizativas, sem que essa perspectiva implique, de modo algum, a busca por um organizar universal. Essa lógica, por sua vez, implica o entendimento e a problematização dos estados de alternância entre estabilidade-instabilidade e desconstrução-construção cotidiana, como sugerido por Cooper.

Cabe pontuar, seguindo Cavalcanti e Alcadipani (2013, p. 562), que pensar dessa forma "não pressupõe um possível 'enfraquecimento"' ou distanciamento do objeto de estudo da administração. Significa caminhar em direção contrária, optando por buscar subsídios conceituais que permitam compreender a natureza mutante da realidade social e denunciar eventuais abusos morais e éticos que sustentam determinadas práticas administrativas. As ideias de Cooper suscitam uma epistemologia focada na descrição e interpretação da organização como processo (in progress), isto é, na captura do que poderíamos chamar de presente etnográfico ${ }^{27}$ das organizações. Essa seria, sem dúvida, uma compreensão política das organizações ou uma compreensão destas como um fenômeno micropolítico.

${ }^{27}$ Apropriação da expressão utilizada pelo antropólogo James Holston (1996). 


\section{REFERÊNCIAS}

ALCADIPANI, R. Academia e a fábrica de sardinhas. Organizações \& Sociedade, v. 18, n. 57, p. 345-348, 2011.

ALCADIPANI, R.; CALDAS, M. P. Americanizing Brazilian management. Critical Perspectives on International Business, v. 8, n. 1, p. 37-55, 2012.

ALCADIPANI, R.; DAVEL, E. Estudos críticos em administração: a produção científica brasileira nos anos 1990. Revista de Administração de Empresas, São Paulo, v. 43, n. 4, p. 72-85, 2003.

ALCADIPANI, R. et al. Southern voices in management and organization knowledge. Organization, v. 19, n. 2, p. 131-143, 2012.

ALVESSON, M. The play of metaphors. In: HASSARD, J.; PARKER, M. (Orgs.) Postmodernism and organizations. [S.I.]: Sage Publication, 1994. cap. 7. 114-131 p.

BARROS, A. et al. Apropriação dos saberes administrativos: um olhar alternativo sobre o desenvolvimento da área. RAM - Revista de Administração Mackenzie, v. 12, n. 5, p. 43-67, $2011 . g$

CARRIERI, A. P.; PERDIGÃO, D. A.; AGUIAR, A. R. C. A gestão ordinária dos pequenos negócios: outro olhar sobre a gestão em estudos organizacionais. Revista de Administração v. 49, n. 4, p. 698-713, 2014.

CAVALCANTI, M. F. R.; ALCADIPANI, R. Organizações como processos e teoria ator-rede : a contribuição de John Law para os estudos organizacionais. Cad. EBAPE.BR, v. 11, n. 4, p. 556-568, 2013.

CLEGG, S. R.; HARDY, C. Introdução: organização e estudos organizacionais. Handbook de Estudos Organizacionais. São Paulo: Atlas, 2010. v. 1. 29-58 p.

COOPER, R. Modernism, post modernism and organizational analysis 3: the contribution of Jacques Derrida. Organization studies, v. 10, n. 4, p. 479-502, 1989.

COOPER, R. Organization/disorganization. In: HASSARD, J.; PYM, D. (Orgs.) The theory and philosophy of organizations: critical issues and new perspectives. [S.I.]: Routledge, 1990. cap. 10. 167-197 p.

COOPER, R; BURRELL, G. Modernism, postmodernism and organizational analysis: an introduction. Organization studies, v. 9, n. 1, p. 91-112, 1988.

DELEUZE, G.; GUATTARI, F. Mil platôs: capitalismo e esquizofrenia 2. São Paulo: Editora 34, 2011. v. 1.

DERRIDA, J. Writing and difference. London: Routledge and Kegan Paul. 1978.

DERRIDA, J. Implicações - entrevista a Henri Ronse. In: DERRIDA, J. Posições. Belo Horizonte: Autêntica, 2001a. 9-22 p.

DERRIDA, J. Semiologia e gramatologia - entrevista a Julia Kristeva. In: DERRIDA, J. Posições. Belo Horizonte: Autêntica, 2001b. 9-22 p.

DERRIDA, J. A estrutura, o signo e o jogo no discurso das ciências humanas. In: DERRIDA, J. A escritura e a diferença. São Paulo: Editora Perspectiva, 2002. 229-249 p.
FERREIRA, R. F.; CALVOSO, G. G.; GONZALES, C. B. L. Caminhos da pesquisa e a contemporaneidade. Psicologia: reflexão e crítica, v. 15, n. 2, p. 243-250, 2002.

FOUCAULT, M. Microfísica do poder. Rio de Janeiro: Edições Graal, 1992.

FRENKEL, M.; SHENHAV, Y. From binarism back to hybridity: a postcolonial reading of management and organization studies. Organization Studies, v. 27, n. 6, p. 855-876, 2006.

GERGEN, R. Organization theory in the postmodern era. In: REED, M.; HUGHES, M. (Org.) Rethinking organization: new directions in organization theory and analysis. [S.I.]: Sage Publications, 1994. cap. 11. 207-226 p.

GOULART, A. T. Notas sobre o desconstrucionismo de Jacques Derrida. 2003. Disponível em: <http://www.pucminas.br/imagedb/mestrado_doutorado/publicacoes/PUA_ARQ ARQUI20121011175312.pdf>. Acesso em: 24 ago. 2015.

HALL, S. A identidade cultural na pós-modernidade. Rio de Janeiro: DP\&A, 2006.

HOLSTON, J. Espaços de cidadania insurgente. Cidadania - Revista do Patrimônio Histórico e Artístico Nacional, v. 24, p. 243-254, 1996.

IBARRA-COLADO, E. Organization studies and epistemic coloniality in Latin America: thinking otherness from the margins. Organization, v. 13, n. 4, p. 463-488, 2006.

LATOUR, B. Jamais fomos modernos. Rio de Janeiro: Editora 34, 1994.

LATOUR, B. A esperança de Pandora: ensaio sobre a realidade dos estudos científicos. Bauru: EDUSC, 2001.

LEFEBVRE, H. Reflexões sobre o estruturalismo e a história. In: 0 método estruturalista: textos básicos de ciências sociais. Rio de Janeiro: Zahar Editores, 1967. 80-103 p.

LIMA, L. R. Desconstruindo a linguística estruturalista: o castelo de Saussure sitiado pelo pensamento de Derrida. In: CONGRESSO NACIONAL DE LINGUAGENS E REPRESENTAÇÕES: LINGUAGENS E LEITURAS, 1., 2009, Ilhéus. Anais... Ilhéus, BA: Universidade Estadual de Santa Cruz, 2009. 1-10 p.

LYOTARD, J. F. The postmodern condition: a report on knowledge. Manchester: Manchester University Press, 1984.

MANNING, P. K. Goffman on organizations. Organization Studies, v. 29, n. 5, p. 677-699, 2008.

MATTOS, P. L. C. L. "Administração é ciência ou arte?" O que podemos aprender com este mal-entendido? Revista de Administração de Empresas, São Paulo, v. 49, n. 3, p. 349-360, 2009.

MIETTINEN, R.; SAMRA-FREDERICKS, D.; YANOW, D. Re-turn to practice: an introductory essay. Organization Studies, v. 30, n. 12, p. 1309-1327, 2010.

MIGUEL, L. F. Consenso e conflito na teoria democrática: para além do "agonismo". Lua Nova. v. 92, p. 13-43, 2014.

MORGAN, G. Paradigms, metaphors, and puzzle solving in organization theory. Administrative Science Quarterly, v. 25, n. 4, p. 605-622, 1980. 
MORGAN, G. More on metaphor: why we cannot control tropes in administrative science. Administrative Science Quarterly, v. 28, n. 4, p. 601-607, dez. 1983.

MOSÉ, V. O homem que sabe: do homo sapiens à crise da razão. Rio de Janeiro: Civilização Brasileira, 2012.

MOSÉ, V. Nietzsche e a grande política da linguagem. Rio de Janeiro: Civilização Brasileira, 2014.

PAES DE PAULA, A. P. Por uma nova gestão pública. São Paulo: Editora FGV, 2005.

PETERS, M. Pós-estruturalismo e filosofia da diferença. Belo Horizonte: Autêntica, 2000.

REED, M. I. Organizations and modernity: continuity and discontinuity in organization theory. In: HASSARD, J.; PARKER, M. (Orgs.). Postmodernism and organizations. [S.I.]: Sage Publications, 1994. cap. 10. 163-182 p.
REED, M. I. Teorização organizacional: um campo historicamente contestado. Handbook de Estudos Organizacionais. São Paulo: Atlas, 2010. v. 1. 61-97 p.

SCHATZKI, T. R. Peripheral vision: the sites of organizations. Organization Studies, v. 26, n. 3, p. 465-484, 2005.

SCHATZKI, T. R. On organizations as they happen. Organization Studies, v. 27, n. 12, p. 1863-1873, 2006.

TSOUKAS, H.; CHIA, R. On organizational becoming: rethinking organizational change. Organization Science, v. 13, n. 5, p. 567582, 2002.

WOLFREYS, J. Différance e escritura. In: WOLFREYS, J. Compreender Derrida. Rio de Janeiro: Vozes, 2009. cap. 2. 73-116 p.

ZILIO, L. B. et al. Organizações contra-hegemônicas e a possibilidade de redescoberta da política na modernidade: uma contribuição a partir do pensamento de Hannah Arendt. Cad. EBAPE.BR, v. 10, n. 4, p. 789-803, 2012. 